\title{
The number of polyploid giant cancer cells and epithelial-mesenchymal transition- related proteins are associated with invasion and metastasis in human breast cancer
}

Fei Fei ${ }^{1}$, Dan Zhang ${ }^{2}$, Zhengduo Yang ${ }^{2}$, Shujing Wang ${ }^{1}$, Xian Wang ${ }^{1}$, Zhengsheng Wu ${ }^{1}$, Qiang Wu ${ }^{1 *}$ and Shiwu Zhang ${ }^{2^{*}}$

\begin{abstract}
Background: Previously, we reported that polyploid giant cancer cells (PGCCs) induced by cobalt chloride $\left(\mathrm{CoCl}_{2}\right)$ could have generated daughter cells with strong invasiveness and migration capabilities via asymmetric divisions. This study compared the expression of epithelial-mesenchymal transition (EMT)-related proteins, including E-cadherin, $\mathrm{N}$-cadherin, and vimentin, between PGCCs and their daughter cells, and control breast cancer cell lines MCF-7 and MDA-MB-231. The clinicopathological significance of EMT-related protein expression in human breast cancer was analyzed.

Methods: Western blot was used to compare the expression levels of E-cadherin, $\mathrm{N}$-cadherin, and vimentin in breast cancer lines MCF-7 and MDA-MB-231, between PGCCs with budding daughter cells and control breast cancer cells. Furthermore, 167 paraffin-embedded breast tumor tissue samples were analyzed, including samples obtained from 52 patients with primary breast cancer with lymph node metastasis (group I) and their corresponding lymph node metastatic tumors (group II), 52 patients with primary breast cancer without metastasis (group III), and 11 patients with benign breast lesions (group IV). The number of PGCCs was compared among these four groups.

Results: The number of PGCCs increased with the malignant grade of breast tumor. Group llhad the highest number of PGCCS and the differences among group I, II, III and IV had statistically significance $(P=0.000)$. In addition, the expression of E-cadherin $(P=0.000), \mathrm{N}$-cadherin $(P=0.000)$, and vimentin $(P=0.000)$ was significantly different among the four groups. Group II exhibited the highest expression levels of $\mathrm{N}$-cadherin and vimentin and the lowest expression levels of E-cadherin.
\end{abstract}

Conclusions: These data suggest that the number of PGCCS and the EMT-related proteins E-cadherin, N-cadherin, and vimentin may be valuable biomarkers to assess metastasis in patients with breast cancer.

Keywords: Polyploid giant cancer cells, Breast cancer, Epithelial-mesenchymal transition, Metastasis

\footnotetext{
*Correspondence: aydjohn@yahoo.com; zhangshiwu666@aliyun.com

1Department of Pathology, Anhui Medical University, Hefei, Anhui 230032,

People's Republic of China

${ }^{2}$ Department of Pathology, Tianjin Union Medicine Center, Tianjin 300121,

P.R China
} 


\section{Background}

Breast carcinoma is the most common cancer and the leading cause of cancer death in women around the world, accounting for $29 \%$ of total new cancer cases in women and the most common causes of cancer death are cancers of the lung and bronchus, breast, and colorectum in women in 2015 [1]. Breast cancer is the leading cause of cancer death in women aged 20 to 59 years [1]. Recurrence and metastasis of breast cancer after surgical removal of the primary tumor are the leading causes of death in breast cancer patients, while present anti-tumor treatment has improved the 5-year survival rate of patients with breast cancer [2]. Currently, the detailed mechanisms of metastasis in breast cancer are complicated, and many proteins and signaling pathways are involved in the process of cancer metastasis.

Recently, we have reported that polyploid giant cancer cells (PGCCs) induced by cobalt chloride $\left(\mathrm{CoCl}_{2}\right)$ are a key contributor to cancer occurrence, development, invasion, metastasis, and chemoresistance [3]. PGCCs are a special sub-population of cancer cells, and the nuclei of PGCCs are usually irregular. PGCC nuclei are at least three times greater in size than regular-sized diploid tumor cell nuclei [4]. They promote the heterogeneity of solid tumors and have the properties of cancer stem cells $[5,6]$. However, the detailed mechanisms of PGCC formation and their relationships with tumor initiation and metastasis are not completely defined. $\mathrm{CoCl}_{2}$ is a hypoxic mimic and can induce the formation of PGCCs by selectively killing regular diploid cells; flow cytometry and fluorescence in situ hybridization (FISH) reveal the presence of multiple copies of DNA in single PGCC [7]. We have successfully isolated, purified, and cultured PGCCs from 22 cancer cell lines, including HEY, SKOV3, and MDA-MB-231 [8]. PGCCs express normal and cancer stem cell markers, and can be induced to differentiate into other tissues, such as adipose, cartilage, erythrocytes, fibroblasts, and bone $[3,4,9,10]$. In addition, they generate daughter cells (regular-sized diploid cancer cells) via asymmetric cell divisions, a process of reductive division known as depolyploidization [11, 12]. Asymmetric cell division, including splitting, budding, and burst-like, usually occurs in the division of low-level eukaryotes, plants, and viruses [3]. Compared to diploid cancer cells, PGCCs with budding daughter cells and PGCCs alone express lower levels of cytokeratin and higher levels of vimentin, indicating that PGCCs and their budding daughter cells have undergone epithelial-mesenchymal transition (EMT) [10].

EMT has been found to play an important role in cancer development and progression. Cancer initiation and progression are complicated processes that are regulated by a variety of cellular and signaling proteins, and often result from malignant epithelial clones that expand as a result of activating mutations of oncogenes or inactivating mutations of tumor suppressor genes. EMT facilitates the metastasis of several types of human cancer, such as bladder cancer, primary liver cancer, and malignant melanoma [13]. The concept of EMT was first put forward by Greenberg et al. [14]. Now, more and more evidence confirms that EMT plays an important role in the process of cancer metastasis [15]. After epithelial cancer cells undergo EMT, they lose epithelial characteristics and cell polarity instead of gaining mesenchymal characteristics, and highly express EMT markers, including snail, slug, and Twist [16]. In addition, the epithelial marker, Ecadherin, and the mesenchymal markers, N-cadherin and vimentin, are regarded as important markers of EMT [17-19], and are widely used in invasion and metastasis cancer research. It is reported that many cancer cells exhibit decreased expression of E-cadherin and increased expression of $\mathrm{N}$-cadherin and vimentin, which are significantly correlated with the malignant degree of cancers and the metastasis of cancers to the lymph nodes. These alterations are in agreement with the EMT phenotype reported in breast cancer [19, 20] and esophageal squamous cell carcinoma [21].

PGCCs and their budding daughter cells gain strong invasiveness and migration ability after they undergo EMT. This study compared the expression of EMTrelated proteins between PGCCs with budding daughter cells and control cells without $\mathrm{CoCl}_{2}$ treatment. We also determined the clinicopathological significance of EMTrelated protein expression and the number of PGCCs in breast cancer.

\section{Methods}

\section{Cancer cell lines and culture}

The human breast cancer cell lines MCF-7 and MDAMB-231 were obtained from the American Type Culture Collection (ATCC; Manassas, VA, USA). MCF-7 cells were maintained in complete ATCC-formulated RPMI1640 medium (HyClone, Logan, UT, USA), and MDAMB-231 cells were grown in ATCC-formulated Leibovitz's L-15 medium (Gibco, Norwalk, CT, USA), supplemented with $10 \%$ fetal bovine serum (FBS; ExCell Bio, Shanghai, China), $100 \mathrm{U} / \mathrm{mL}$ penicillin, and $100 \mu \mathrm{g} / \mathrm{mL}$ streptomycin. Cells were routinely incubated at $37{ }^{\circ} \mathrm{C}$ and $5 \%$ $\mathrm{CO}_{2}$ under a humidified atmosphere.

\section{Formation of PGCCs}

MCF-7 and MDA-MB-231 cells were cultured in complete medium in T25 flasks until they reached 80 $90 \%$ confluence. The cells were cultured with different concentrations of $\mathrm{CoCl}_{2}$ (Sigma-Aldrich, St. Louis, MO, USA) for different periods based on their hypoxiaresistance ability. MCF-7 cells were treated with $450 \mu \mathrm{M}$ $\mathrm{CoCl}_{2}$ for $72 \mathrm{~h}$, and MDA-MB-231 cells were cultured with $300 \mu \mathrm{M} \mathrm{CoCl} 2$ for $72 \mathrm{~h}$. The cells were then 
cultured in regular complete medium after being rinsed with phosphate-buffered saline (PBS). The majority of regular-sized cells died following treatment with $\mathrm{CoCl}_{2}$, and only scattered PGCCs survived $\mathrm{CoCl}_{2}$ treatment. Ten to 15 days after removal of $\mathrm{CoCl}_{2}$, the surviving PGCCs started to generate daughter cells via budding. After three or four additional $\mathrm{CoCl}_{2}$ treatments (to acquire a sufficient number of PGCCs), the PGCCs cultured in complete medium with newly budding daughter cells (approximately $30 \%$ PGCCs with $70 \%$ budding daughter cells) were used for western blots and later analysis.

\section{Cell cycle analysis}

Cells $\left(0.5 \times 10^{6}-1 \times 10^{6}\right)$ were collected by trypsinization and washing in cold PBS twice. Ice-cold $75 \%$ ethanol was slowly added to cells while vortexing gently, and cells were fixed overnight at $4{ }^{\circ} \mathrm{C}$. Then, the cells were rinsed with cold PBS three times, centrifuged at $1000 \mathrm{rpm} /$ min for $5 \mathrm{~min}$, and resuspended in 200-500 $\mu \mathrm{L}$ cold PBS. Next, the cell suspension was incubated with $20 \mu \mathrm{L}$ RNase A (BestBio, Shanghai, China) for $30 \mathrm{~min}$ at $37^{\circ} \mathrm{C}$, and then with $400 \mu \mathrm{L}$ propidium iodide (BestBio) for $30 \mathrm{~min}$ at $4{ }^{\circ} \mathrm{C}$ in a dark room. Analyses and measurements were performed on an FACSVerse (BD Biosciences, Franklin Lakes, NJ, USA) flow cytometer at the excitation wavelength of $488 \mathrm{~nm}$.

\section{Western blot analysis}

PGCCs (30 \%) of MCF-7 and MDA-MB-231 after $\mathrm{CoCl}_{2}$ treatment with budding daughter cells (70 \%), and control cells without $\mathrm{CoCl}_{2}$ treatment were lysed for $30 \mathrm{~min}$ on ice with 100-200 $\mu \mathrm{L}$ ice-cold radio-immunoprecipitation assay (RIPA) lysis buffer, and centrifuged at 12,000 rpm/ $\min$ for $30 \mathrm{~min}$ at $4{ }^{\circ} \mathrm{C}$. Protein concentration was determined, and protein were separated on a $10 \%$ sodium dodecyl sulfate (SDS) polyacrylamide gel and transferred to a polyvinylidene fluoride (PVDF) membrane (Beyotime, Haimen, China). After blocking with $5 \%$ nonfat milk in $1 \times$ Tris-buffered saline with $0.05 \%$ Tween-20 for $3 \mathrm{~h}$ at $20-25{ }^{\circ} \mathrm{C}$, the membranes were incubated with rabbit anti-E-cadherin polyclonal (1:300 dilution; BIOSS, Woburn, MA, USA), rabbit anti-N-cadherin polyclonal (1:300 dilution; BIOSS), rabbit anti-vimentin polyclonal (1:300 dilution; BIOSS), and mouse anti- $\beta$-actin monoclonal (1:800 dilution; Zhongshan Inc., Beijing, China) antibodies overnight at $4{ }^{\circ} \mathrm{C}$. Membranes were then incubated with the appropriate dilution of secondary antibodies at $20-25{ }^{\circ} \mathrm{C}$ for $2 \mathrm{~h}$. SuperSignal West Femto Substrate (ECL detection kit, Thermo Scientific, Norwalk, CT, USA) was used to detect protein expression. Images were captured on a film processor and the optical density of each protein band detected was analyzed with Image-J software. All western blot experiments were repeated multiple times, with $\beta$-actin being used as a protein-loading control.

\section{Cell migration assay}

The migration of control and $\mathrm{CoCl}_{2}$-treated MCF-7 and MDA-MB-231 PGCCs with their budding daughter cells was detected using wound-scratch and transwell migration assays. Cells $\left(1 \times 10^{5}\right.$ cells per well) were seeded in triplicate into 6-well plates and cultured for 24-48 h until they reached an appropriate level of confluence. The wound-scratch assay was performed by uniformly scratching the monolayer of cells with sterile pipette tips, and the cells were washed three times with PBS. Then, serum-free medium was added in place of complete medium. Cell migration was photographed and measured in several pre-marked areas at $0 \mathrm{~h}, 24 \mathrm{~h}$, and $48 \mathrm{~h}$. Here, the cell migration area was measured between dashed regions by Image-J software and normalized to the control cells. The wound-healing index was calculated using the following formula: [(the wound area at $0 \mathrm{~h}$ ) - (the wound area at indicated time)]/(the wound area at $0 \mathrm{~h}$ ).

The transwell migration assay was performed using cell culture inserts $(8 \mu \mathrm{m}$; BD-Falcon, Franklin Lakes, NJ, USA) inserted into a 24-well plate. Cells $\left(5 \times 10^{4}\right.$ cells per insert) in $100 \mu \mathrm{L}$ fresh medium with $1 \%$ FBS were added to the upper chamber, while growth medium with $20 \%$ FBS was added to the lower chamber. Plates were then incubated for $20-24 \mathrm{~h}$ at $37^{\circ} \mathrm{C}$. After removing the non-migrated cells and medium in the upper chamber, the migrated cells retained on the lower side of the membranes were fixed with $95 \%$ methanol for $10 \mathrm{~min}$ and stained with $0.1 \%$ crystal violet for $30 \mathrm{~min}$. Photos were obtained at $\times 100$ magnification, and cells were counted in at least three different areas. Three independent experiments were performed.

\section{Cell invasion assay}

Invasion by control and $\mathrm{CoCl}_{2}$-treated $\mathrm{MCF}-7$ and MDA-MB-231 cells was measured using transwell invasion assays. Cells $\left(5 \times 10^{5}\right.$ per well $)$ were seeded in $100 \mu \mathrm{L}$ medium with $1 \%$ FBS onto inserts pre-coated with BD Matrigel Basement Membrane Matrix (BD Biosciences). Growth medium, with $20 \%$ FBS as the chemoattractant, was added to the bottom chamber, and plates were incubated for $24-36 \mathrm{~h}$ at $37{ }^{\circ} \mathrm{C}$. After the medium and non-invaded cells in the upper chamber were removed, the transwell inserts were fixed with $95 \%$ methanol for $10 \mathrm{~min}$ and stained with $0.1 \%$ crystal violet for $30 \mathrm{~min}$. Photos were taken at $\times 100$ magnification, and the number of invaded cells was counted in multiple different fields. Three independent experiments were performed. 


\section{Tissue samples}

Paraffin-embedded human breast tumor tissue samples $(n=167)$ were obtained from The First Affiliated Hospital of Anhui Medical University (Hefei, China) between 2011 and 2012. None of the patients had received treatment before surgical removal of the tumor. Two pathologists verified the diagnoses of breast tumors. These 167 cases of breast tumors were divided into four groups: 52 cases of primary breast cancer with lymph node metastasis (group I), and their corresponding metastatic lymph nodes (group II); 52 cases of primary breast cancer without metastasis (group III); and 11 cases of benign breast tumors, including breast fibroadenoma and mammary gland disease (group IV). The detail information of patients in group I and group III including the ER/PR expression, lymph node metastasis and Ki-67 expression lists in Additional file 1: Table S1. The agreement for use of these tissue samples was approved by the Biomedical Ethics Committee of Anhui Medical University, and the confidentiality of patient information was maintained.

\section{PGCC definition and counting}

PGCC are defined as cancer cells with a nucleus that is at least three times larger than that of a diploid cancer cell, as described by Zhang et al. [3]. PGCCs are not always evenly distributed throughout the sections, and the number of PGCCs in the hot spots was counted. For each case, five microscopic hot fields were counted at $\times 400$ magnification, and the average number was calculated.

\section{Feulgen staining and ploidy verification}

First, 4- $\mu \mathrm{m}$ sections were deparaffinized and dehydrated with xylene and ethanol. Second, the sections were hydrolyzed with $5 \mathrm{M} \mathrm{HCl}$ for $50 \mathrm{~min}$ at room temperature (setting for $25-30{ }^{\circ} \mathrm{C}$ ). Third, sections were washed with $1 \mathrm{M} \mathrm{HCl}$ followed by distilled water. Finally, sections were stained in Schiff's reagent for $60 \mathrm{~min}$ at room temperature, which was followed by dehydration of the sections with ethanol and xylene, and mounting with a resinous membrane.

For ploidy verification of PGCC, we used the imaging analysis software (Image-Pro Plus, Version 6.0.0.260; Media Cybernetics, Inc., Rockville, MD, USA). After Feulgen staining, typical images under the same conditions of PGCCs and control breast epithelial cells were captured. After viewing the image and choosing the area of control breast epithelial cell distribution, the software was used to calculate the area and integrated optical density (IOD). Then, we computed the mean optical density (MOD) of control breast epithelial cells. Similarly, we used the software to determine the MOD of
PGCCs, and then we compared the ratio of MOD of PGCCs to that of control breast epithelial cells.

\section{Immunohistochemical (IHC) staining}

All 4- $\mu \mathrm{m}$-thick sections were subjected to two-step immunohistochemical (IHC) staining. Briefly, the sections were deparaffinized in xylene, and dehydrated in a set of graded ethanol solutions. Then, antigen retrieval was carried out by heating in $0.01 \mathrm{M}$ citrate buffer solution (pH 6.0) with an autoclave at $120{ }^{\circ} \mathrm{C}$ for $5 \mathrm{~min}$ [22]. After endogenous peroxidase activity was blocked, the slides were incubated with the primary antigens overnight at $4{ }^{\circ} \mathrm{C}$, including mouse anti-E-cadherin monoclonal antibody (MAB-0589; Maixin Bio, Fuzhou, China, 1:200 dilution), mouse anti-N-cadherin monoclonal antibody (ZM-0094; Zhongshan Inc., China, 1:100 dilution), and mouse anti-pig vimentin monoclonal antibody (kit-0019, ZM-0094; Maixin Bio, Fuzhou, China, 1:200 dilution), Slides were then washed three times with PBS for $5 \mathrm{~min}$. Next, the sections were incubated with horseradish peroxidase-conjugated secondary antibody, rinsed another three times with PBS for 5 min, incubated with 3, 3'-diaminobenzidine (DAB, Zhongshan Inc.) for 1-3 min, and finally counterstained with hematoxylin. Known positive samples were used as positive controls, while the negative controls were run simultaneously by replacing the primary antibody with PBS.

\section{IHC scoring and quantification}

Slide assessment was independently carried out by two experienced pathologists. In the evaluation of E-cadherin, $\mathrm{N}$-cadherin, and vimentin expression, brown-yellow staining in the cytomembrane and/or cytoplasm was considered positive for expression. Expression within the tissue sections was quantified according to the staining intensity and percentage of positive cells. The staining intensity was scored as follows: 0 , negative (no staining); 1 , weak positive (faint yellow staining); 2, moderate positive (brownish-yellow staining); and 3 , strong positive (brown staining). The number of positive cells was visually evaluated and stratified as follows: 0 (negative), $<5 \%$ positive cells; 1 (weak), $6 \%-25 \%$ positive cells; 2 (moderate), $26 \%-50 \%$ positive cells; 3 (above moderate), $51 \%$ $75 \%$; and 4 (strong), $>76 \%$ positive cells [21]. The sum of the staining intensity and positive cell scores was used to determine the staining index for each section [23].

\section{Statistical analysis}

Statistical software SPSS 17.0 for Windows was used to analyze all the statistical data in this study. All histogram data are presented as mean $\pm \mathrm{SD}$, and all table data are presented as mean \pm SEM. The Kruskal-Wallis test was 

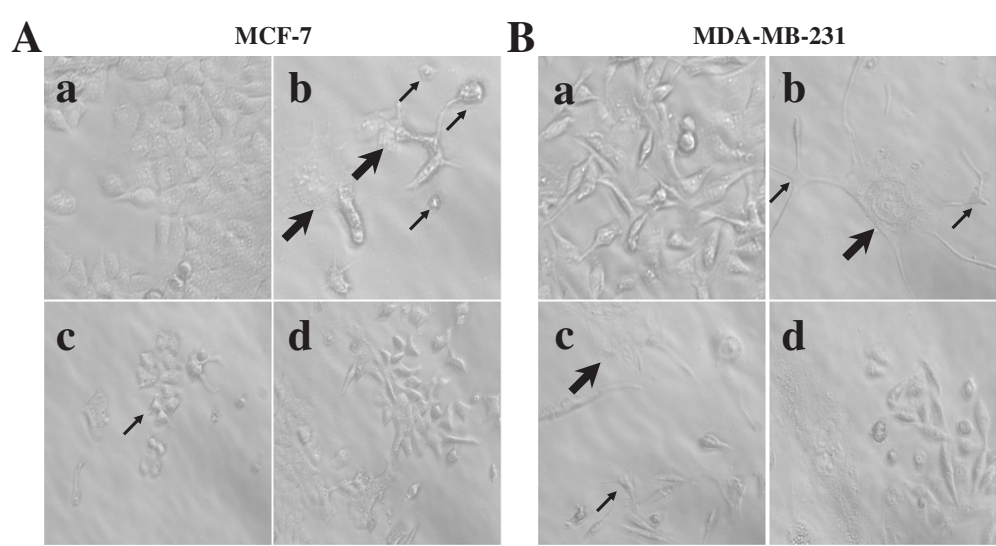

Fig. 1 PGCCs with budding daughter cells in MCF-7 and MDA-MB-231 cells. A. MCF-7 PGCCs and control MCF-7 cells. a. Control MCF-7 cells (×400). b. MCF-7 PGCCs induced by $450 \mu \mathrm{M} \mathrm{CoCl} 2$ treatment for $72 \mathrm{~h}$ (×400). Small black arrowheads indicate budded daughter cells; large black arrow heads indicate PGCCs. c. PGCCs generated daughter cells via budding 10-15 days after $\mathrm{CoCl}_{2}$ treatment. Black arrowheads indicate budded daughter cells $(\times 100)$. d. Fast reproduction of PGCCs by generated daughter cells via budding ( $\times 100)$. B. MDA-MB-231 PGCCs and control MDA-MB-231

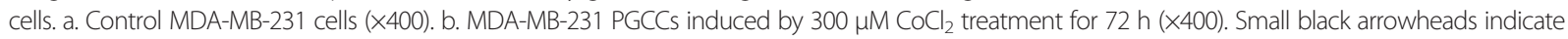
budded daughter cells; large black arrowheads indicate PGCCs. C. PGCCs generated daughter cells via budding 10-15 days after $\mathrm{CoCl}_{2}$ treatment. Small black arrowheads indicate budded daughter cells; large black arrowheads indicate PGCCs $(\times 100)$. $d$. Recovery of PGCCs by generated budding daughter cells $(\times 100)$

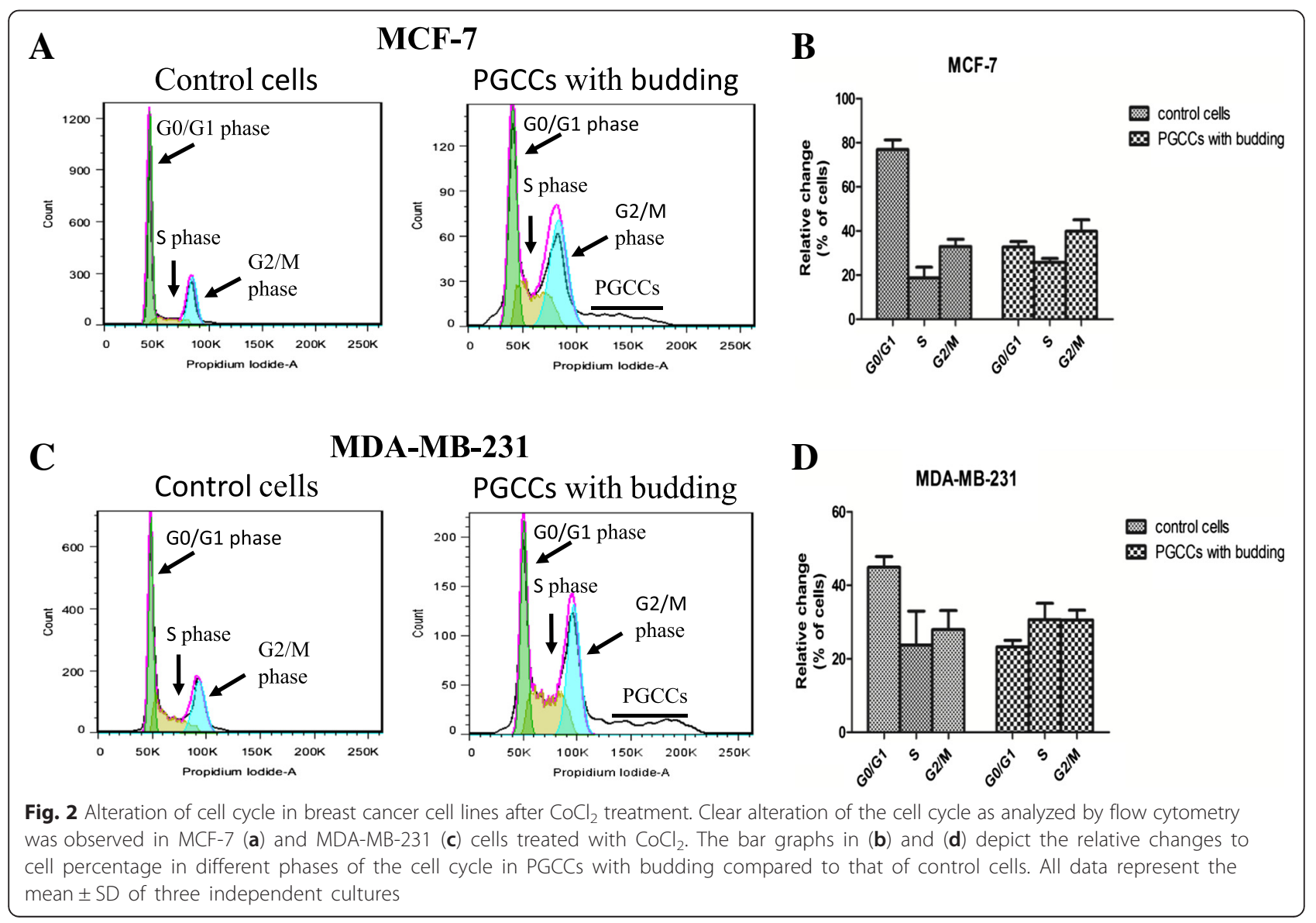


performed to compare the differences in PGCC number and EMT-related protein expression among the four groups. The Mann-Whitney test was used to analyze the differences in PGCC number and EMT-related protein expression between two groups of the four. Other comparisons were performed with a two-tailed Student's $t$-test. Here, a $p$-value $<0.05$ was considered statistically significant.

\section{Results}

\section{$\mathrm{CoCl}_{2}$-induced PGCC formation in breast cancer cells}

When the breast cancer cell lines MCF-7 and MDAMB-231 were treated with high concentrations of $\mathrm{CoCl}_{2}$ over a long period, normal-sized diploid cancer cells were selectively killed while some large cells with giant nuclei (PGCCs) survived. After a high concentration $\mathrm{CoCl}_{2}$ treatment $(450 \mu \mathrm{M})$ of MCF-7 cells for $72 \mathrm{~h}$ killed most diploid cells, PGCCs could be observed after removal of floating dead cells, in contrast to the control MCF-7 cells (Fig. 1A-a and A-b). Similar morphological changes were observed for the MDA-MB-231 breast cancer cell line (Fig. 1B-a and B-b). At 10-15 days post$\mathrm{CoCl}_{2}$ treatment, the surviving PGCCs cultured in complete medium generated daughter cells via budding (Fig. 1A-c and B-c). The number of regular-sized daughter cells increased from $60 \%$ to $70 \%$ after $24 \mathrm{~h}$ of continuous culture in complete medium, while the percentage of PGCCs in the flask decreased from $40 \%$ to $30 \%$ (Fig. 1A-d and B-d). These PGCCs with budding cells and control cells were used for the cell cycle and EMT-related protein expression analyses.

Cell cycle analysis in breast cancer cells before and after $\mathrm{CoCl}_{2}$ treatment

$\mathrm{CoCl}_{2}$-induced alterations to the cell cycle in various phases in MCF-7 and MDA-MB-231 cells was observed

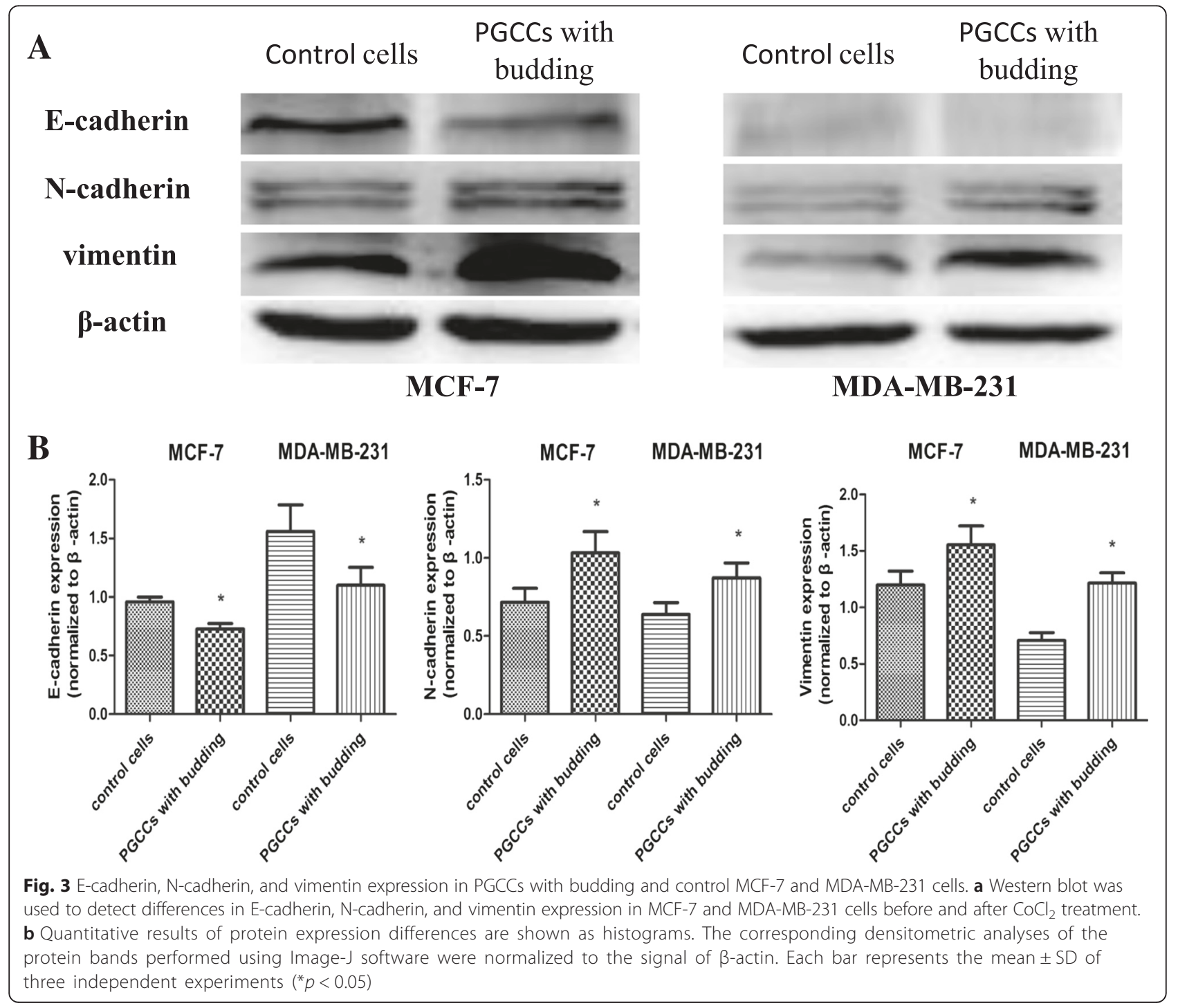


using flow cytometry (Fig. 2a and c). We observed a sharp decrease in the number of $\mathrm{CoCl}_{2}$-treated cells in G1 phase, but an increase in the number of cells in S and G2 phases (Fig. 2b and d). In addition, flow cytometric analysis confirmed that cells treated with $\mathrm{CoCl}_{2}$ generated a cell subpopulation corresponding to PGCCs, which had a large increase in DNA copy number.

\section{EMT-related protein expression in control breast cancer cells and PGCCs with budding}

The expression of EMT-related proteins, including Ecadherin, N-cadherin, and vimentin, was analyzed in control MCF-7 and MDA-MB-231 cells and in PGCCs with budding cells. Western blot analysis revealed that E-cadherin expression was lower in PGCCs with budding than in control cells, and that expression of $\mathrm{N}$ cadherin and vimentin was greater in PGCCs with budding than in control cells (Fig. 3a). A quantitative analysis of EMT-related protein expression in PGCCs with budding and control cells is depicted in Fig. $3 \mathrm{~b}$. The densitometric analyses of each protein band were normalized to the corresponding $\beta$-actin band, which revealed a significant difference between PGCCs with budding and control cells.

\section{Daughter cells budded by PGCCs have great migration and invasion abilities}

To determine whether $\mathrm{CoCl}_{2}$ treatment affects cell migration in the breast cancer cell lines MCF-7 and MDA-MB-231, a wound-healing assay was performed on PGCCs with budding and control cells. Fig. 4a and c depict the wound-scratch assay at $0 \mathrm{~h}, 24 \mathrm{~h}$, and $48 \mathrm{~h}$. The spaces between the red dashed lines gradually narrowed in the panels. The quantitative analysis reveals a

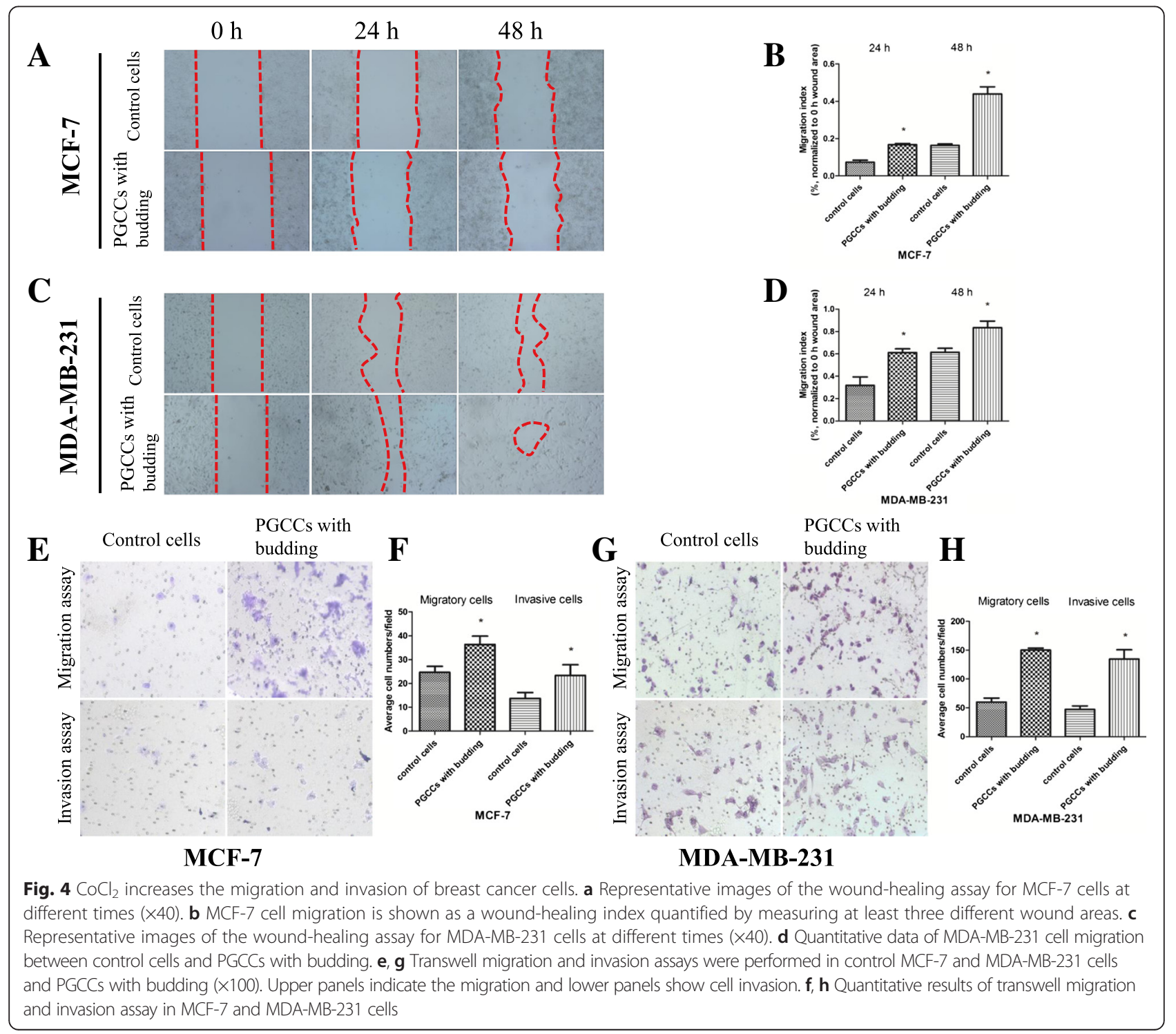


significant increase in the cell migration ability of PGCCs with budding (Fig. 4b and d). Moreover, we also performed a transwell migration assay with MCF-7 and MDA-MB-231 cells to compare PGCCs with budding and control cells. As shown in Fig. 4e and g, the number of migrated cells increased in PGCCs with budding cells compared with the control cells. To examine whether $\mathrm{CoCl}_{2}$ treatment affects cell invasion in MCF-7 and MDA-MB-231 cells, the cell invasion assay was performed using matrigel-coated transwell inserts. Invaded cell numbers also greatly increased in the group of PGCCs with budding cells compared to control cells (Fig. 4e and g). Quantitative results of transwell migration and invasion assays in MCF-7 and MDA-MB-231 cells indicated significant differences in the numbers of migratory and invasive cells (Fig. 4f and $\mathrm{h}$ ).

\section{Clinicopathological significance of the number of PGCCs in human breast tumors}

Using the description of PGCCs set by Zhang et al. [3], we observed morphologically that PGCCs with giant or multiple nuclei were significantly present in human breast tumors of group I, group II, and group III (Fig. 5). As shown in Table 1, group II had the highest number of PGCCs and group III had the lowest; the difference between these groups was statistically significant $(P=$ 0.000). PGCCs were not observed in group IV. The average number of PGCCs was higher in group II than in group I $(\mathrm{Z}=-7.402, P=0.000)$, higher in group I than in group III $(\mathrm{Z}=-6.278, P=0.000)$, and higher in group III than in group IV $(\mathrm{Z}=-5.196, P=0.000)$.

Feulgen staining and mean optical density determination To observe the nuclei morphologies of PGCCs in human breast tumor tissues, we performed Feulgen staining. Feulgen staining, in which DNA is dyed purple, revealed the distribution of DNA in tumor cells (Fig. 6a). The images were captured at $\times 200$ magnification, analyzed by Image-Pro Plus software, and the MOD of control breast epithelial cells and PGCCs was calculated. Three further images of normal breast tissue and breast cancer were obtained and analyzed. By analyzing these images, we determined an average optical density value for normal breast epithelium, fluctuating between 14 and 19, and determined the MOD of PGCCs to be in the range of 40 to 90 , positively correlating with the volume of PGCCs. The ratio of PGCC and control breast epithelial cell approximations was an integer greater than or equal to 2 . Compared with normal diploid mammary epithelial cells, the polyploidy nature of PGCCs human breast tumor tissue was confirmed. Quantitative results of MOD determinations are shown in Fig. 6b.
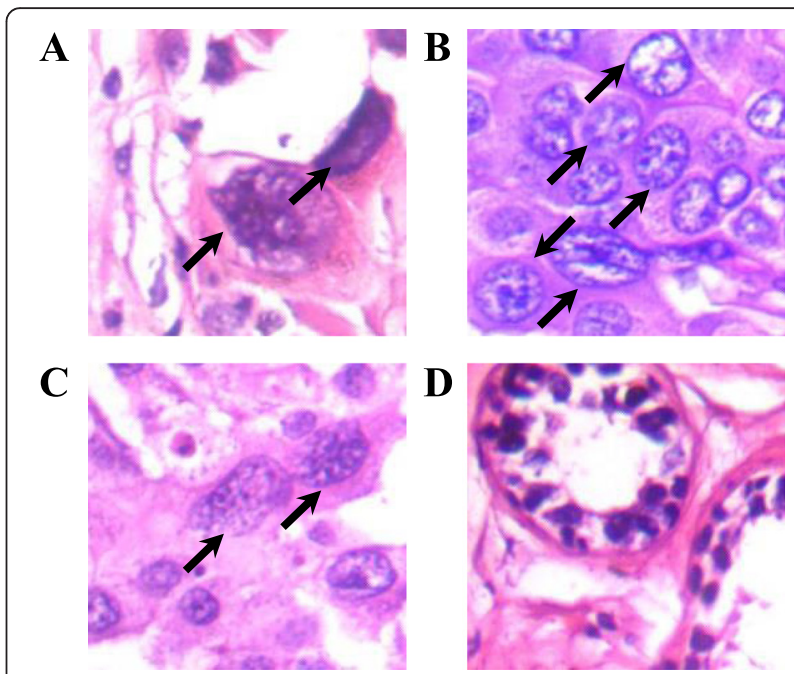

Fig. 5 PGCCs in human breast tumors. a PGCCs in primary breast cancer with metastasis (group I; black arrowheads, H\&E, $\times 400$ ). b PGCCs in metastatic tumors (group Il; black arrowheads, H\&E, $\times 400$ ). c PGCCS in primary breast cancer without metastasis (group III; black arrowheads, H\&E, $\times 400)$. d PGCCs are absent in benign breast tumors (group IV; H\&E, $\times 400$ )

\section{Expression of EMT-related proteins in human breast tumor tissues}

To detect the expression level of EMT-related proteins and their clinicopathological significance, IHC staining for E-cadherin, $\mathrm{N}$-cadherin, and vimentin was performed on 167 cases of formalin-fixed, paraffin-embedded human breast tumor tissues. Positive E-cadherin (Fig. 7a) staining appeared in the cytomembrane or cytoplasm of tumor cells, positive N-cadherin (Fig. 7b) staining was detected in the cytomembrane, and positive vimentin staining was present in the cytoplasm (Fig. 7c). Ecadherin $(P=0.000)$, N-cadherin $(P=0.000)$, and vimentin $(P=0.000)$ staining indexes were significantly different between the four groups (Table 2). Metastatic cancer (group II) exhibited the highest N-cadherin and vimentin expression, and the lowest E-cadherin expression (Fig. 7 and Table 2). Benign breast tumors (group IV) had the highest E-cadherin expression, and the lowest

Table 1 Comparison of the average number of PGCCs in human breast tumors

\begin{tabular}{llllll}
\hline & Group & Number & $\begin{array}{l}\text { Number of } \\
\text { PGCCs }\end{array}$ & $X^{2}$ & $\begin{array}{l}P \\
\text { value }\end{array}$ \\
\hline $\begin{array}{l}\text { Primary breast cancer } \\
\begin{array}{l}\text { with lymph node } \\
\text { metastasis }\end{array}\end{array}$ & 52 & $22.62 \pm 1.15$ & 125.193 & 0.000 \\
$\begin{array}{l}\text { Corresponding } \\
\text { metastatic tumor }\end{array}$ & $\|$ & 52 & $41.04 \pm 1.49$ & & \\
$\begin{array}{l}\text { Primary breast cancer } \\
\text { without metastasis }\end{array}$ & II & 52 & $11.35 \pm 0.90$ & & \\
$\begin{array}{l}\text { Benign breast tumor } \\
\text { IV }\end{array}$ & 11 & 0 & & \\
\hline
\end{tabular}




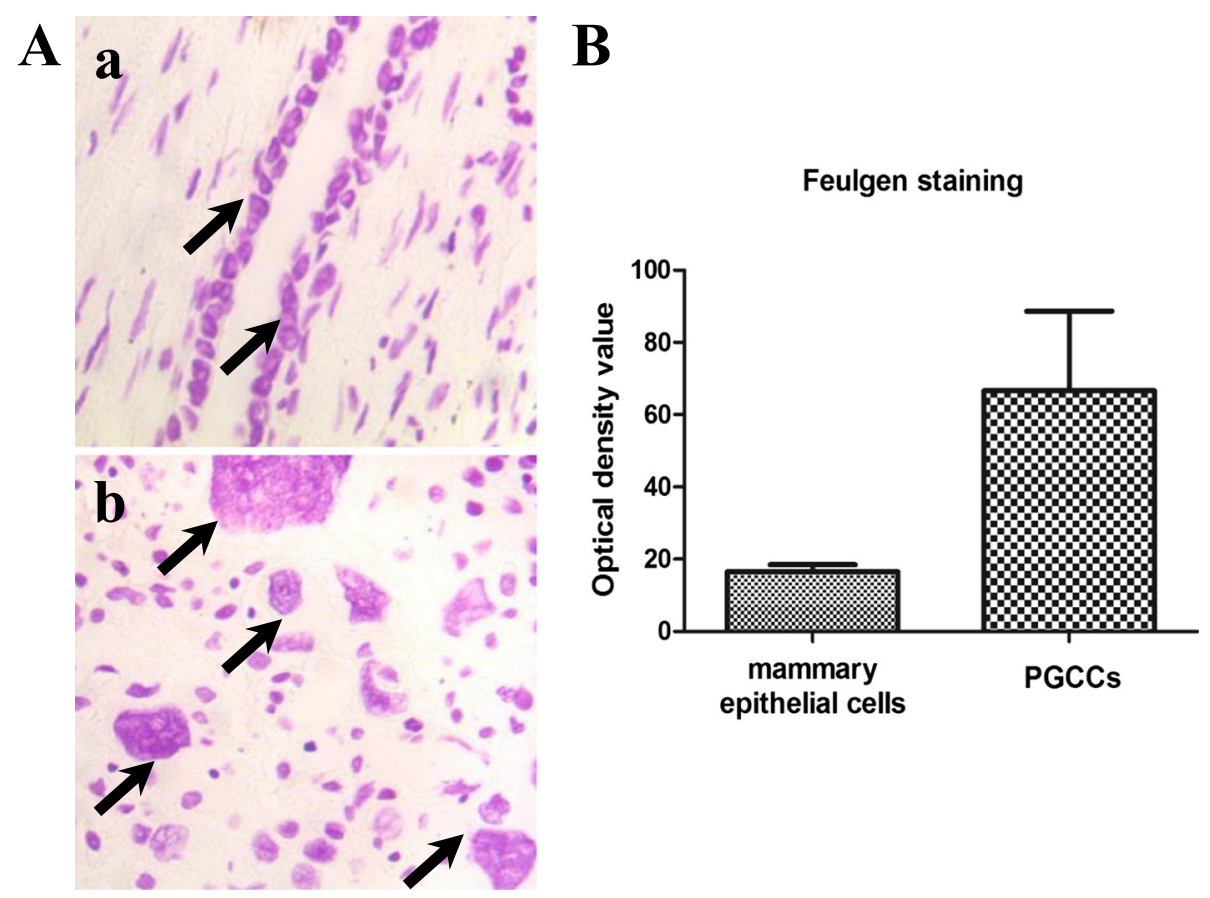

Fig. 6 Feulgen staining and MOD determination of PGCCs and control mammary epithelial cells. A. Feulgen staining between PGCCS and control mammary epithelial cells. a. Feulgen staining of mammary epithelial cells (black arrowheads, $\times 200$ ). b. Feulgen staining of PGCCs in breast cancer (black arrowheads, ×200). B. Quantitative results of MOD determination in PGCCs and control mammary epithelial cells

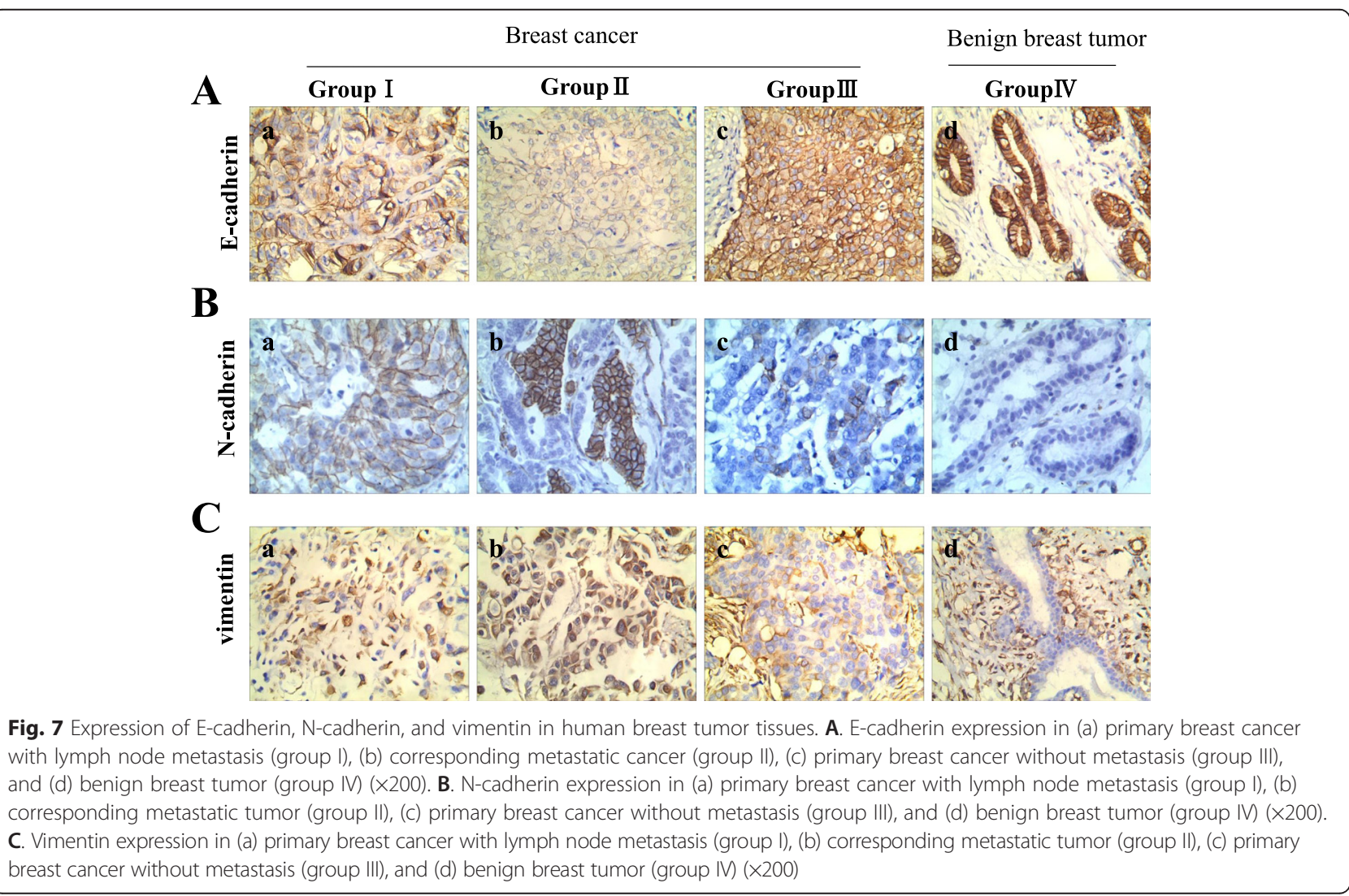


$\mathrm{N}$-cadherin and vimentin expression (Fig. 7 and Table 2). Statistical analysis revealed that the expression of Ncadherin and vimentin was higher in group II than in group I $(Z=-2.856, P=0.004 ; Z=-2.347, P=0.019$; respectively; Table 3$)$, higher in group I than in group III $(\mathrm{Z}=-2.736, P=0.006 ; \mathrm{Z}=-3.545, P=0.000$; respectively; Table 4), and higher in group III than in group IV ( $\mathrm{Z}=-$ $1.592, \quad P=0.111 ; \quad Z=-2.524, \quad P=0.012 ;$ respectively; Table 5). The staining indices of N-cadherin and vimentin were significantly different between group I and group II and between group I and group III. Moreover, the expression of E-cadherin was lower in group II than in group I $(Z=-2.713, P=0.007$; Table 3$)$, lower in group I than in group III $(\mathrm{Z}=-2.720, P=0.007$; Table 4$)$, and lower in group III than in group IV $(\mathrm{Z}=-1.246, P=$ 0.213; Table 5). The differences in E-cadherin expression were statistically significant between group I and group II, and between group I and group III. Furthermore, PGCCs in group I (Fig. 8 -a) and group III (Fig. 8 -e) undergo EMT and IHC staining for E-cadherin, Ncadherin and vimentin in group I (Fig. 8 -b,-c,-d) and group III (Fig. $8-\mathrm{f}$,-g,-h) were performed. Results of IHC staining showed that single stroma PGCC located in the invasive front of primary breast cancer with metastasis were strong positive for N-cadherin (Fig. 8 -c) and vimentin (Fig. 8 -d) and weak positive for Ecadherin (Fig. 8 -b). Single stroma PGCC in group III had the similar expression of N-cadherin (Fig. 8 -g), vimentin (Fig. 8 -h) and E-cadherin (Fig. 8 -e) as it in primary breast cancer with metastasis.

\section{Discussion}

PGCCs are large and contain single giant nuclei or multiple nuclei and are a special sub-population of cancer cells that contribute to solid tumor heterogeneity. PGCCs are the most commonly described histopathologic features of human tumors, particularly in high-

Table 2 The differences of E-cadherin, $\mathrm{N}$-cadherin, and vimentin expression in human breast tumors

\begin{tabular}{|c|c|c|c|c|c|}
\hline & Group & Number & E-cadherin & $\mathrm{N}$-cadherin & vimentin \\
\hline $\begin{array}{l}\text { Primary breast } \\
\text { tumor with } \\
\text { metastasis }\end{array}$ & I & 52 & $9.67 \pm 0.34$ & $0.96 \pm 0.19$ & $1.96 \pm 0.24$ \\
\hline $\begin{array}{l}\text { Corresponding } \\
\text { metastatic } \\
\text { tumor }\end{array}$ & $\|$ & 52 & $8.38 \pm 0.34$ & $1.81 \pm 0.28$ & $3.02 \pm 0.35$ \\
\hline $\begin{array}{l}\text { Primary breast } \\
\text { tumor without } \\
\text { metastasis }\end{array}$ & III & 52 & $10.90 \pm 0.26$ & $0.46 \pm 0.12$ & $0.92 \pm 0.15$ \\
\hline $\begin{array}{l}\text { Benign breast } \\
\text { tumor }\end{array}$ & IV & 11 & $11.64 \pm 0.36$ & $0.09 \pm 0.09$ & $0.18 \pm 0.12$ \\
\hline$x^{2}$ & & & 35.267 & 31.455 & 45.777 \\
\hline$P$ & & & 0.000 & 0.000 & 0.000 \\
\hline
\end{tabular}

Table 3 The differences of E-cadherin, $\mathrm{N}$-cadherin, and vimentin expression between group I and group ||

\begin{tabular}{|c|c|c|c|c|c|}
\hline & Group & Number & E-cadherin & $\mathrm{N}$-cadherin & vimentin \\
\hline $\begin{array}{l}\text { Primary breast } \\
\text { tumor with } \\
\text { metastasis }\end{array}$ & I & 52 & $9.67 \pm 0.34$ & $0.96 \pm 0.19$ & $1.96 \pm 0.24$ \\
\hline $\begin{array}{l}\text { Corresponding } \\
\text { metastatic tumor }\end{array}$ & $\|$ & 52 & $8.38 \pm 0.34$ & $1.81 \pm 0.28$ & $3.02 \pm 0.35$ \\
\hline Z & & & -2.713 & -2.856 & -2.347 \\
\hline$P$ & & & 0.007 & 0.004 & 0.019 \\
\hline
\end{tabular}

grade and advanced-stage tumors, and usually correlate with poor prognosis (ref) (Malpica et al., 2004; Polyak, 2011; Wolberg et al., 1999). PGCCs have been considered as senescent cells, or as at the stage of mitotic catastrophe, but our previous data revealed that these large cancer cells were actually live and could generate daughter cancer cells via budding [3, 4]. PGCCs were initially observed in flasks after high concentrations of $\mathrm{CoCl}_{2}$ treatment, which selectively killed regular diploid cells of HEY, SKOV3, and MDA-MB-231 cancer cells [3]. $\mathrm{CoCl}_{2}$ can induce the formation of PGCCs through endoreduplication or cell fusion, and PGCCs can generate daughter cancer cells via asymmetric cell division, including splitting, budding, and burst, which commonly appears in lower organisms [3, 9, 10]. The daughter cells generated by PGCCs exhibit mesenchymal phenotypes, and have stronger migration and invasion abilities than those of regular diploid cancer cells. In this paper, we characterized a PGCC as a cancer cell with a nucleus at least three times larger than that of a diploid cancer cell.

Recently, more studies have confirmed that EMT plays an important role in tumor invasion and metastasis [2426]. In the present study, we investigated the expression of three EMT-related proteins, including E-cadherin, Ncadherin, and vimentin, in PGCCs with budding daughter cells and control cancer cells without $\mathrm{CoCl}_{2}$ treatment. Furthermore, the expression of these proteins was compared in human breast tumor tissues, and IHC staining showed that expression of these proteins was associated with breast tumor lymph node metastasis.

Table 4 The differences of E-cadherin, $\mathrm{N}$-cadherin, and vimentin expression between group I and group III

\begin{tabular}{|c|c|c|c|c|c|}
\hline & Group & Number & E-cadherin & $\mathrm{N}$-cadherin & vimentin \\
\hline $\begin{array}{l}\text { Primary breast } \\
\text { tumor with } \\
\text { metastasis }\end{array}$ & I & 52 & $9.67 \pm 0.34$ & $0.96 \pm 0.19$ & $1.96 \pm 0.24$ \\
\hline $\begin{array}{l}\text { Primary breast } \\
\text { tumor without } \\
\text { metastasis }\end{array}$ & III & 52 & $10.90 \pm 0.26$ & $0.46 \pm 0.12$ & $0.92 \pm 0.15$ \\
\hline Z & & & -2.720 & -2.736 & -3.545 \\
\hline$P$ & & & 0.007 & 0.006 & 0.000 \\
\hline
\end{tabular}


Table 5 The differences of E-cadherin, $\mathrm{N}$-cadherin, and vimentin expression between group III and group IV

\begin{tabular}{llllll}
\hline & Group & Number & E-cadherin & N-cadherin & vimentin \\
\hline $\begin{array}{l}\text { Primary breast } \\
\text { tumor without }\end{array}$ & & 52 & $10.90 \pm 0.26$ & $0.46 \pm 0.12$ & $0.92 \pm 0.15$ \\
$\begin{array}{l}\text { metastasis } \\
\begin{array}{l}\text { Benign breast } \\
\text { tumor }\end{array}\end{array}$ & & & & & \\
$Z$ & & & $11.64 \pm 0.36$ & $0.09 \pm 0.09$ & $0.18 \pm 0.12$ \\
$P$ & & -1.246 & -1.592 & -2.524 \\
\hline
\end{tabular}

E-cadherin, a calcium-dependent single-span transmembrane glycoprotein, has been widely known as a tumor suppressor and a characterized molecular marker of EMT [27], and is an important epithelial cell adhesion molecule and signal transduction factor located in the epithelial tissue [25]. The cytoplasmic domain of Ecadherin interacts with many proteins, including three catenins $(\alpha, \beta$, and p120), and combines with the actin cytoskeleton. E-cadherin sets up close alloantigen interactions with contiguous E-cadherin molecules in neighboring cells to form the core of the epithelial adherens junction [28, 29]. Loss of E-cadherin can lead to enhanced tumor mobility and invasion [30, 31].

$\mathrm{N}$-cadherin is also a calcium-dependent glycoprotein. Unlike E-cadherin, $\mathrm{N}$-cadherin is absent in normal epithelium, and promotes a dynamic adhesion state in tumor cells, allowing not only the separation of single cells from the tumor entity but also their interactions with endothelial and stromal components [32-34]. Expression of $\mathrm{N}$-cadherin is further increased in tumors with metastatic potential and is up-regulated in many cancers, including breast invasive ductal carcinomas [24, 34, 35], colorectal cancers [36, 37], esophageal squamous cell carcinomas [21], and non-small cell lung cancers [38].

Vimentin, an important component of the cytoskeleton, is widely distributed in mesenchymal cells such as endothelial cells, lymphocytes, and fibroblasts [25, 39]. As another well-known marker of EMT, several studies have shown that the abnormal expression of vimentin was present in many kinds of epithelial tumors and associated with the invasion and metastasis of cancer cells $[40,41]$. Furthermore, the overexpression of vimentin in breast cancer cells is correlated with poor prognosis, leading to adverse clinicopathological features in patients $[39,42]$. EMT is known as a cadherin switching process, leading to primary molecular changes, including the loss of epithelial cell markers and overexpression of mesenchymal cell markers [43-45].

In the present study, we confirmed that the expression of E-cadherin was down-regulated, and that the expression of $\mathrm{N}$-cadherin and vimentin was up-regulated in PGCCs with budding daughter cells. By detecting EMTrelated proteins in cancer cell lines, we estimate that the migration and invasion ability of the daughter cells budded from PGCCs could be attributed to EMT. Furthermore, more PGCCs were detected in the group of breast

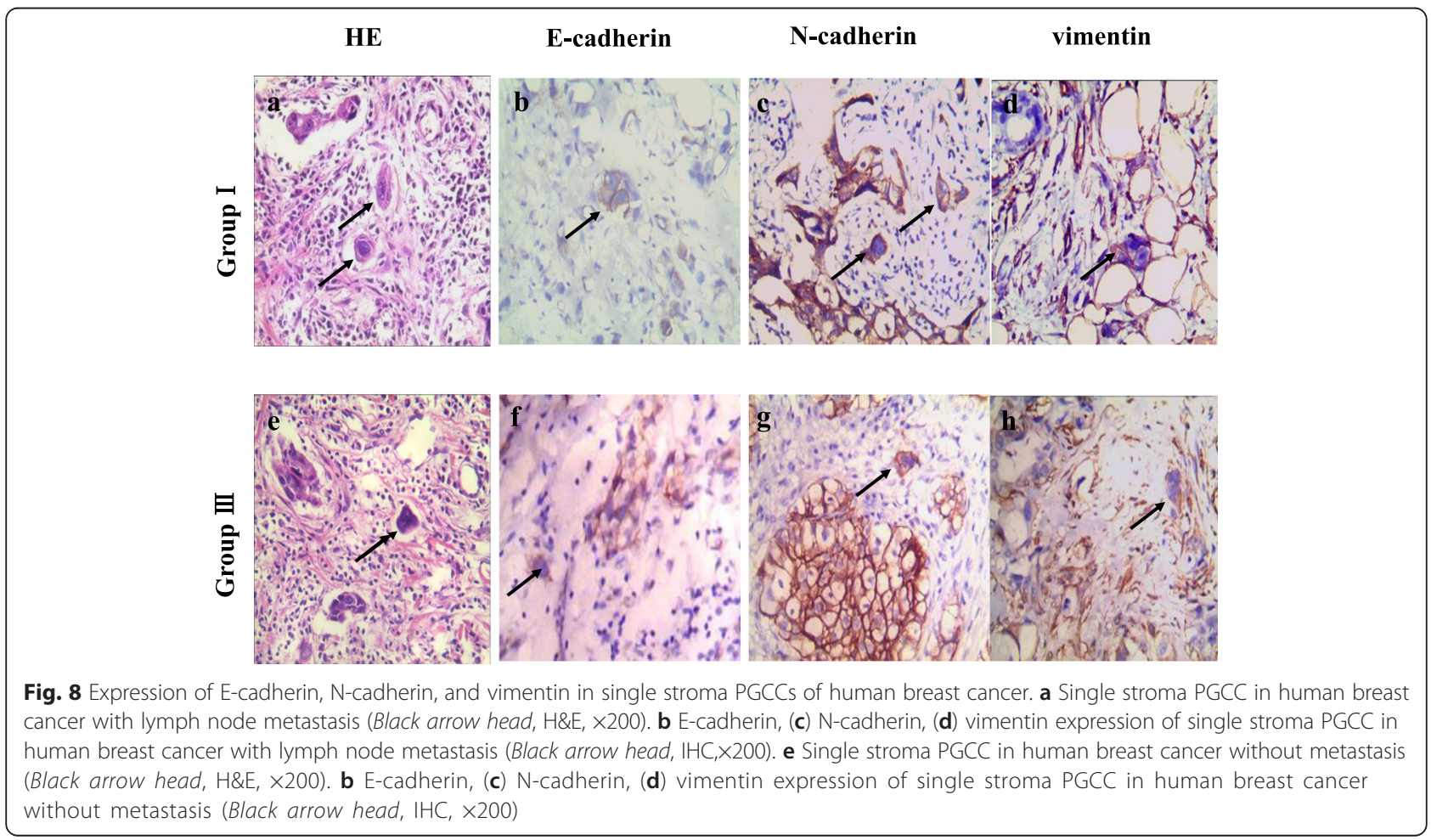


tumors with metastasis than in the group without metastasis. Finally, expression of E-cadherin was downregulated, while expression of $\mathrm{N}$-cadherin and vimentin was up-regulated, in primary breast carcinomas with metastasis and their metastatic foci, compared with primary breast carcinomas without metastasis and benign breast lesions. These data further demonstrate that the number of PGCCs and EMT-related protein expression are associated with invasion and metastasis in breast cancer. However, the mechanisms of PGCCs formation and EMT involving in daughter cells generated by PGCCs via budding are still unclear. Sequencing and cGH analysis focused on the genetic heterogeneity of PGCCs at the levels of mutation and genomic rearrangements need to be performed in the future.

\section{Conclusions}

The current study introduces the novel concept that PGCCs are present in human breast cancer, and that PGCCs with their newly budding daughter cells contribute to the occurrence of EMT-associated cancer invasion and metastasis. Further exploration of the mechanisms of PGCC formation and EMT-related protein expression in the development, invasion, and metastasis of breast cancer is needed.

\section{Additional file}

Additional file 1: Table-S1. Detail information of patients in group I and group III. (DOC $27 \mathrm{~kb}$ )

\section{Abbreviations \\ $\mathrm{CoCl}_{2}$ : cobalt chloride; DAB: diaminobenzidine; EMT: epithelial-mesenchymal transition; FBS: fetal bovine serum; FISH: fluorescence in situ hybridization; IHC: immunohistochemistry; IOD: integrated optical density; MOD: mean optical density; PBS: phosphate-buffered saline; PGCCs: Polyploid giant cancer cells; PVDF Membrane: polyvinylidene fluoride membrane; SDS: sodium dodecyl sulfate.}

\section{Competing interests}

The authors declare that they have no competing interest.

\section{Authors' contributions}

FF conducted the experiments and drafted the manuscript. DZ, ZY and XW participated in the sample collection and statistical analysis. ZW helped in the design of the study. QW and SZ conceived of the study, and participated in its design and coordination and helped to draft the manuscript. All authors have read and approved the final manuscript.

\section{Acknowledgements \\ This work was supported in part by grants from the National Natural Science Foundation of China (81472729 and 81372476), the Foundation of Ministry of Education of China (2014-1685), the foundation of committee on science and technology of Tianjin (13JCYBJC42700).}

Received: 1 October 2015 Accepted: 18 December 2015 Published online: 24 December 2015

\section{References}

1. Torre LA, Bray F, Siegel RL, Ferlay J, Lortet-Tieulent J, Jemal A. Global cancer statistics, 2012. CA Cancer J Clin. 2015;65(2):87-108.
2. Kennecke H, Yerushalmi R, Woods R, Cheang MC, Voduc D, Speers CH, et al. Metastatic behavior of breast cancer subtypes. J Clin Oncol Off J Am Soc Clin Oncol. 2010;28(20):3271-7.

3. Zhang S, Mercado-Uribe I, Xing Z, Sun B, Kuang J, Liu J. Generation of cancer stem-like cells through the formation of polyploid giant cancer cells. Oncogene. 2014;33(1):116-28.

4. Zhang S, Mercado-Uribe I, Liu J. Generation of erythroid cells from fibroblasts and cancer cells in vitro and in vivo. Cancer Lett. 2013;333(2):205-12

5. Marusyk A, Almendro V, Polyak K. Intra-tumour heterogeneity: a looking glass for cancer? Nat Rev Cancer. 2012;12(5):323-34.

6. Zhang S, Zhang D, Zhu Y, Guo H, Zhao XBS. Clusterin expression and univariate analysis of overall survival in human breast cancer. Technol Cancer Res Treat. 2006;5(6):573-8.

7. Lopez-Sánchez LM JC, Valverde A, Hernandez V, Peñarando J, Martinez A, Lopez-Pedrera C, et al. CoCl2, a Mimic of Hypoxia, Induces Formation of Polyploid Giant Cells with Stem Characteristics in Colon Cancer. PLoS One. 2014;9(6):e99143.

8. Zhang D, Wang Y, Zhang S. Asymmetric cell division in polyploid giant cancer cells and low eukaryotic cells. BioMed Res Int. 2014;2014:432652.

9. Zhang S, Mercado-Uribe I, Liu J. Tumor stroma and differentiated cancer cells can be originated directly from polyploid giant cancer cells induced by paclitaxel. Int J Cancer: Journal international du cancer. 2014;134(3):508-18.

10. Zhang S, Mercado-Uribe I, Hanash S, Liu J. iTRAQ-based proteomic analysis of polyploid giant cancer cells and budding progeny cells reveals several distinct pathways for ovarian cancer development. PLoS One. 2013;8(11), e80120.

11. Vitale I, Senovilla L, Jemaa M, Michaud M, Galluzzi L, Kepp O, et al. Multipolar mitosis of tetraploid cells: inhibition by p53 and dependency on Mos. EMBO J. 2010;29(7):1272-84.

12. Erenpreisa J, Salmina K, Huna A, Kosmacek EA, Cragg MS, lanzini F, et al. Polyploid tumour cells elicit paradiploid progeny through depolyploidizing divisions and regulated autophagic degradation. Cell Biol Int. 2011:35(7):687-95.

13. Mani SA, Guo W, Liao MJ, Eaton EN, Ayyanan A, Zhou AY, et al. The epithelial-mesenchymal transition generates cells with properties of stem cells. Cell. 2008;133(4):704-15.

14. Greenburg G, Hay ED. Epithelia suspended in collagen gels can lose polarity and express characteristics of migrating mesenchymal cells. J Cell Biol. 1982:95(1):333-9.

15. Zhao Z, Lu P, Zhang H, Xu H, Gao N, Li M, et al. Nestin positively regulates the $\mathrm{Wnt} / \beta$-catenin pathway and the proliferation, survival and invasiveness of breast cancer stem cells. Breast Cancer Res. 2014;16(4):408.

16. Tran DD, Corsa CA, Biswas H, Aft RL, Longmore GD. Temporal and spatial cooperation of Snail1 and Twist1 during epithelial-mesenchymal transition predicts for human breast cancer recurrence. Mol Cancer Res: MCR. 2011:9(12):1644-57.

17. Jin HMS, Sato F, Kudo Y, Akasaka H, Tsutsumi S, Ogasawara H, et al. Vimentin expression of esophageal squamous cell carcinoma and its aggressive potential for lymph node metastasis. Biomed Res. 2010;31(2):105-12

18. Li K, Wang X, He W, Lin N, Fan QX. Expression of N-cadherin in esophageal squamous cell carcinoma and silencing expression of N-cadherin using RNA interference on invasiveness of EC9706 cells. Ai Zheng. 2009;28(1):8-13.

19. Onder TT, Gupta PB, Mani SA, Yang J, Lander ES, Weinberg RA. Loss of E-cadherin promotes metastasis via multiple downstream transcriptional pathways. Cancer Res. 2008;68(10):3645-54.

20. Kumar KJ, Vani MG, Chueh PJ, Mau JL, Wang SY. Antrodin C inhibits epithelial-to-mesenchymal transition and metastasis of breast cancer cells via suppression of Smad2/3 and beta-catenin signaling pathways. PLoS One. 2015;10(2), e0117111.

21. Pang L, Li Q, Wei C, Zou H, Li S, Cao W, et al. TGF-beta1/Smad signaling pathway regulates epithelial-to-mesenchymal transition in esophageal squamous cell carcinoma: in vitro and clinical analyses of cell lines and nomadic Kazakh patients from northwest Xinjiang, China. PLoS One. 2014; 9(12), e112300.

22. Li KDH, Lian X, Yang S, Chai D, Wang C, Yang R, et al. Characterization of $\beta 2$-microglobulin expression in different types of breast cancer. BMC Cancer. 2014;14:750

23. Di Martino E, Wild CP, Rotimi O, Darnton IS, Olliver RJ, Hardie $\sqcup$, IGFBP-3 and IGFBP-10 (CYR61) up-regulation during the development of Barrett's 
oesophagus and associated oesophageal adenocarcinoma: potential biomarkers of disease risk. Biomarkers: Biochemical indicators of exposure, response, and susceptibility to chemicals. 2006;11(6):547-61.

24. ElMoneim HM, Zaghloul NM. Expression of e-cadherin, $\mathrm{n}$-cadherin and snail and their correlation with clinicopathological variants: an immunohistochemical study of 132 invasive ductal breast carcinomas in Egypt. Clinics (Sao Paulo). 2011;66(10):1765-71.

25. Zhou J, Tao D, Xu Q, Gao Z, Tang D. Expression of E-cadherin and vimentin in oral squamous cell carcinoma. Int J Clin Exp Pathol. 2015;8(3):3150-4.

26. Qu BL, Yu W, Huang YR, Cai BN, Du LH, Liu F. 6-OH-BDE-47 promotes human lung cancer cells epithelial mesenchymal transition via the AKT/Snail signal pathway. Environ Toxicol Pharmacol. 2015;39(1):271-9.

27. Le Bras GF, Taubenslag KJ, Andl CD. The regulation of cell-cell adhesion during epithelial-mesenchymal transition, motility and tumor progression. Cell Adhes Migr. 2012;6(4):365-73.

28. Gumbiner BM. Regulation of cadherin-mediated adhesion in morphogenesis. Nat Rev Mol Cell Biol. 2005;6(8):622-34

29. Nagafuchi A, Shirayoshi Y, Okazaki K, Yasuda K, Takeichi M. Transformation of cell adhesion properties by exogenously introduced E-cadherin CDNA. Nature. 1987;329(6137):341-3.

30. Derksen PW, Liu X, Saridin F, van der Gulden H, Zevenhoven J, Evers B, et al. Somatic inactivation of E-cadherin and p53 in mice leads to metastatic lobular mammary carcinoma through induction of anoikis resistance and angiogenesis. Cancer Cell. 2006;10(5):437-49.

31. Baranwal S, Alahari SK. Molecular mechanisms controlling E-cadherin expression in breast cancer. Biochem Biophys Res Commun. 2009;384(1):6-11.

32. Tomita K, van Bokhoven A, van Leenders GJ, Ruijter ET, Jansen CF, Bussemakers MJ, et al. Cadherin switching in human prostate cancer progression. Cancer Res. 2000;60(13):3650-4.

33. Li G, Herlyn M. Dynamics of intercellular communication during melanoma development. Mol Med Today. 2000;6(4):163-9.

34. Hazan RB, Phillips GR, Qiao RF, Norton L, Aaronson SA. Exogenous expression of $\mathrm{N}$-cadherin in breast cancer cells induces cell migration, invasion, and metastasis. J Cell Biol. 2000;148(4):779-90.

35. Nagi C, Guttman M, Jaffer S, Qiao R, Keren R, Triana A, et al. N-cadherin expression in breast cancer: correlation with an aggressive histologic variant-invasive micropapillary carcinoma. Breast Cancer Res Treat. 2005;94(3):225-35.

36. Ye Z, Zhou M, Tian B, Wu B, Li J. Expression of IncRNA-CCAT1, E-cadherin and $\mathrm{N}$-cadherin in colorectal cancer and its clinical significance. Int J Clin Exp Med. 2015;8(3):3707-15.

37. Yan X, Yan L, Liu S, Shan Z, Tian Y, Jin Z. N-cadherin, a novel prognostic biomarker, drives malignant progression of colorectal cancer. Mol Med Rep. 2015:12(2):2999-3006.

38. Hui L, Zhang S, Dong X, Tian D, Cui Z, Qiu X. Prognostic significance of twist and N-cadherin expression in NSCLC. PLoS One. 2013;8(4):e62171.

39. Karihtala P, Auvinen P, Kauppila S, Haapasaari KM, Jukkola-Vuorinen A, Soini Y. Vimentin, zeb1 and Sip1 are up-regulated in triple-negative and basal-like breast cancers: association with an aggressive tumour phenotype. Breast Cancer Res Treat. 2013;138(1):81-90.

40. Yamashita N, Tokunaga E, Kitao H, Hisamatsu Y, Taketani K, Akiyoshi S, et al. Vimentin as a poor prognostic factor for triple-negative breast cancer. J Cancer Res Clin Oncol. 2013;139(5):739-46.

41. Yao X, Wang X, Wang Z, Dai L, Zhang G, Yan Q, et al. Clinicopathologica and prognostic significance of epithelial mesenchymal transition-related protein expression in intrahepatic cholangiocarcinoma. OncoTargets and Therapy. 2012;5:255-61.

42. Liu T, Zhang X, Shang M, Zhang Y, Xia B, Niu M, et al. Dysregulated expression of Slug, vimentin, and E-cadherin correlates with poor clinical outcome in patients with basal-like breast cancer. J Surg Oncol. 2013:107(2):188-94

43. Wheelock MJ, Shintani Y, Maeda M, Fukumoto Y, Johnson KR. Cadherin switching. J Cell Sci. 2008;121(Pt 6):727-35.

44. Scanlon CS, Van Tubergen EA, Inglehart RC, D'Silva NJ. Biomarkers of epithelial-mesenchymal transition in squamous cell carcinoma. J Dent Res. 2013;92(2):114-21.

45. Turley EA, Veiseh M, Radisky DC, Bissell MJ. Mechanisms of disease: epithelial-mesenchymal transition-does cellular plasticity fuel neoplastic progression? Nat Clin Pract Oncol. 2008;5(5):280-90.

\section{Submit your next manuscript to BioMed Central and we will help you at every step:}

- We accept pre-submission inquiries

- Our selector tool helps you to find the most relevant journal

- We provide round the clock customer support

- Convenient online submission

- Thorough peer review

- Inclusion in PubMed and all major indexing services

- Maximum visibility for your research

Submit your manuscript at www.biomedcentral.com/submit
Biomed Central 